\title{
Timothy Findley's War Novels
}

\author{
J. A. Zabalbeascoa \\ Universidad de Alcalá de Henares
}

\begin{abstract}
Timothy Findley has shown a deep concern for the most outstanding historical events of the 20th century, seen from the point of view of a Canadian citizen with a remarkable European vocation. Two of his best known novels are The Wars and Famous Last Words. The first one depicts the spiritual nightmare undergone by a Canadian lieutenant during World War I. The technique used for Famous Last Words is completely different and the view of the world at war refers to the period 1940-1945. This other novel depicts the activities of historical characters, besides fictitious ones. We have never felt the presence of evil so disturbing as with this extravagant tale that sounds like "the truth," because the memory of the events is still so vivid that it will outlive several generations of human beings.
\end{abstract}

With the exception of perhaps Mavis Gallant, no other Canadian story teller has looked abroad with more interest and intensity than Timothy Findley. He has applied his talent to several artistic media, from his early career on the stage up to his present success as a novelist. Due to the limited extension of this paper, we are going to concentrate our attention on his narrative work and more precisely on two of his best known novels: The Wars and Famous Last Words.

Madness and violence are two axis around which Findley's main stories evolve. His second novel, The Butterfly Plague (1969) brings into focus other characteristics also, among them the tendency to translate the devices that the cinema has popularized into narrative technique. The Butterfly Plague combines fictional violence with historical horrors. Set in Hollywood, amid the movie crowd, it compares the crazy mentality of its characters with the uncontrolable madness that spread across Germany when Hitler got into power.

Several years lapsed until Findley picked up again the idea of war in Europe. In the meantime he had become a famous script writer for a popular TV series, such as Jalna and The National Dream. The Wars (1977), perhaps his best novel so far, is a moving and 
frightening depiction of the apocalyptical experience of trench warfare in World War I. In the process The Wars becomes an apprenticeship novel, just in the same way that, for instance, The Longest Journey by E. M. Forster. It is not a Bildungsroman, because the subject is not autobiographical-Findley was born in 1930-you may call it Entwicklungsroman or whatever, but in plain words, the plot deals with a young man growing up into maturity during a time of terrible stress.

The novels about World War I have made a long list (Everything is Quiet on the Western Front, Three Soldiers, A Farewell to Arms, The Soldier's Pay, etc.), but, in spite of having to compare with formidable competitors, The Wars holds its place brilliantly as one of the most moving stories ever written on that subject, thanks to Findley's superb ability in handling his material.

The most important accomplishment has to do with point of view. The book is divided into four parts. In the first one war is slowly approaching Robert Ross' life. We are given his family background and military training. The other three deal with his experiences in the battlefields, mingled with excerpts of his love affair with a beautiful aristocratic young lady.

The prologue of the first part states the dramatic event that causes Robert's downfall and extinction. It is written in the third person and the event is repeated near the end of the novel. However, Findley has not merely made use of flashbacks, as most of contemporary novelists do; he has contrived a peculiar and poignant way of rearranging the story.

Each part of the book is divided into small fragments, never more than two or three pages long, and sometimes as short as a few sentences. Fragment number one-they are all numbered starting from one in each part-in the first part produces a helpful insight in regard to the narrator's attitude. He tells the reader that he is going to use second hand material according to several eye witnesses of what happened to Robert Ross. He is certainly not one of Robert's contemporaries. He never shared with the Canadian lieutenant-not even with his fellow nationals-the haunting experiences he is about to unfold; but he is going to try his best to take us, the readers, as near the events as he possibly can. He struggles to put the reader in Robert's boots and, from this first fragment, addresses us in a confidential manner, indicating the best way in which to proceed.

Fragment two starts with these words: "You begin at the archives with photographs." That means that the narrator is going to use old family snapshots and letters and recorded interviews with eye witnesses in order to gather all the facts. He is working for us, the readers, and he can sound intimate and familiar, but, at the same time, remain sufficiently detached to analize minutely his own proceedings. "All you can hear is the wristwatch on your arm. Outside, it snows. The dark comes early. The archivist is gazing from her desk. She coughs. The boxes smell of yellow dust. You hold your breath. As the past moves under your fingertips, part of it crumbles. Other parts, you know you'll never find. That is what you have" (11).

Through the detailed description of the old snapshots and the faithful transcription of the tapes, the narrator reconstructs the story of a shy young man called Robert Ross, who marched candidly into an international war and ended his life consumed by flames. At the beginning of the novel the photos show us our hero in the company of his family and reveal his deep love for his crippled sister, Rowena, who sits in a wheelchair and holds a 
white rabbit on her lap. By the way, the rabbit is only the first one in a long series of animals that appear through the novel, each one carrying a special significance. In general terms in Findley's novel, animals evoke sensitive feelings missing in most of the human relationships.

Once the narrator has taught the reader how to animate the scenes that appear in the photos, he proceeds to narrate Robert's initiation to holocaust in the third person. But he never forgets to remind us that we must put aside our callousness, acquired through many years now of getting familiar with formidable means of destruction and go back to the mentality of people that moved from a romantic idea of war into the machinery of total destruction. By and by the narrator reverts to photographs and tapes again, in order to maintain the reader's tension, which is necessary to "interpret" events with the candid eyes of an old-fashioned observer. In the article about The Wars this process is described by Vladimir Timanov as "de-automatization." Timanov borrows the concept ostranenie (stranny is "strange" in Russian) from an article by Victor Shklovsky, the title of which is "Art as Technique" when translated from Russian.

Ostranenie can be achieved by different methods. The most simple one is "through the explication of a simple concept that we normally accept automatically, without giving it a second thought" (108). And Shklovsky uses a passage of Tolstoy explaining minutely how criminals are flogged. Tolstoy's words reenact the scene so vividly that we feel it as a personal experience. Another type of ostranenie is "achieved when a phenomenon familiar to the reader is presented directly through the eyes of a character unfamiliar with the phenomenon" (110).

Timanov finds plenty of examples of this technique in The Wars, illustrating what we said before about the way Findley manages to make the reader get into the hero's boots and feel as if he himself was a young lieutenant, innocent and sensitive, suddenly drafted into a maddening nightmare. This technique is especially effective not only in the trench warfare scences, but also in sexual depictions. The way in which some homosexual experiences are made particularly disturbing would provide material for a longer article. But after all ostranenie is a concept adapted from Roman Jakobson's theory exposed in his article, "Two Aspects of Language and Two Types of Aphasia," which gave birth to a similar concept, aktualisace, coined by the Praga School of Linguistics. David Lodge, the English professor turned into famous novelist, translated aktualisace into "foregrounding" in his book The Modes of Modern Writing (9).

As we said before, insanity and violence seem to be two constant features in Findley's narrative, as he himself confessed to professor Donald Cameron in an interview:

Findley I know that my speculations would be that what is beautiful is sinister, rather than what is sinister is beautiful, because I have no overt sadism in me and I have no overt masochism. The balance in me I think is fairly even. I am not a masochist and I am not a sadist in the given sense of either of those words. I have a little of both in me, but I'm sure as hell not sadistic enough to really think that anything sinister is beautiful. But at the same time, this funny thing always rises up in me, which is the thing about insanity. There's always someone who must do insane things in order to clarify what, for want of better words, is bright and good. (55) 
Insanity and violence, whether in war of peaceful times, brings us to Findley's next novel, Famous Last Words. Especially insanity, since in the very first pages the reader witnesses a scene in which Hugh Selwyn Mauberiey is listening to his father's lessons about life on the top floor of the Arlington Hotel in Boston before Mr. Mauberley Sr. "clambered onto the ledge and-waving at the sky-he lept down fifteen stories to his death" (2).

Whereas The Wars deals with World War I, Famous Last Words is about World War II, but there are more differences than similarities between these two books. First of all, the characters. Most of them-or at least the main ones-were fictional in the previous novel. Quite the opposite happens in Famous Last Words, most of the characters are "real" people, who played important roles in the international scene just before and during World War II. We have mentioned Hugh S. Mauberley, the main character. He is fictional alright, but not created by Findley. The Canadian novelist, inspired by Ezra Pound's famous poem, has reinvented his "persona" and cast him among the historical events that preceded and followed Hitler's rise to power.

The main story is told by Mauberley, who we "see" speaking to Pound and his wife in the first chapters; but Mauberley's whereabouts are framed by an anonymous narrator, who, by means of a discovery, introduces Hugh's "famous last words," written at the end of the war: an American patrol arrives at the Austrian hotel where he has been atrociously murdered and lieutenant Quinn is fascinated by the writing on the walls, because it is precisely on the walls of the old Grand Elysium Hotel in the Tyrol where Mauberley has left his anxious testimony painfully written with a silver pencil.

The technique applied in the pages given to the anonymous narrator-omniscient, and therefore, less appealing to the reader than the one in The Wars-is based on the ostranenie that we explained before: very detailed descriptions of the most disturbing scenes, in order to involve the reader emotionally; as, for instance, when the American soldiers turn over with great effort and care Mauberley's corpse and discover he has been hit in one eye with a pickaxe.

The structure of Famous Last Words is much more complex than in the previous novel. Dates at the beginning of each chapter and section help the reader to focus on the different periods along which the plot develops. Furthermore, each chapter is headed by a quotation ad hoc taken from works by W. H. Auden, T. S. Eliot and, of course, Ezra Pound, especially from Hugh Selwyn Mauberley (Life and Contacts). Besides, the novel opens after a quotation from The Ides of March by T. Wilder.

In the first chapter-following the introduction that depicts Mauberly Sr.'s suicide-the anonymous narrator unfolds Hugh's own hardships and sufferings since his escape away from Rapallo, which is about to be occupied by the Allies, up to the moment he has finally arrived to the Grand Elysium Hotel in the Tyrol, an obvious allusion to "the other world" prompted by Pound's words.

The next chapter starts with the arrival of the American troops at the hotel in May, 1945, two months later. By then Mauberley is dead, but previously he has covered the walls of several rooms with his memoirs. It is sympathetic Quinn who reads the writing on the walls and so we have the story of Hugh's whereabouts between 1924 and 1945, delivered in the first person. However, his words also refer to historical events, filled in 
with private conversations between influential people of those times to which Mauberley doesn't seem to be privy. Therefore, the "dialoges" are made up, if not some of the events. Finally, the novel ends with a rather pretentious philosophical reflexion in the mind of honest Quinn about some dark menace which defies reason.

About the mixture of historical and fictional characters, which seems to be the vogue in recent postmodern fiction, Timothy Findley spoke to B. Meyer and B. O'Riordan in an interview recorded in 1984:

Interviewers In Famous Last Words, you employ the mode of what might be called historical fiction of fictionalized history, which you also used in The Wars. What were the difficulties and the advantages of employing such a mode? How do you determine how to treat characters like the Duke or Duchess of Windsor, Ezra Pound, Sir Harry Oaks, etc.?

Findley My first part of the answer has to be that you don't put them in unless there's something about the aura, or the story, or whatever, that draws you to them as people. It is not enough to want them in the plot and then, for instance, throw in the Duke and Duchess of Windsor. You've got to really want to know them as people. The thing that's interesting, particularly with Wallis (the Duchess) was the more I wrote about her the more she became mine. Something about her seemed to be inside me, to come from inside. There's no question all of this comes from inside you.

Interviewers It's the shared humanity, then, the universality?

Findley Yes, it's the universality. It's also that in some instances there are people you get rid of very quickly. They pass in and out of their moment in the book and it hasn't really affected you. They're walk-ons in the true sense. (46)

By the way, we reckon that Findley could have dispensed with the second plot about Captain Freyberg's and Lieutenant Quinn's animosity. It adds very little to the emotional impact of the book and distracts the reader.

Mauberley's "autobiography" depicts the activities of a certain number of people, who moving in the rearguard of the great confrontation, tried to gather an élite of influential friends, in order to obtain world power. Historical characters, such as the Duke and Duchess of Windsor, von Ribbentrop, Lindbergh, Ezra Pound, etc., are mixed with fictitious ones. The trouble is that, in spite of its international flavor, the narrative lacks the intensity and pathos of Robert Ross' experience. Very little fighting at the different fronts is exposed and the events that surround the Duke's imposed exile hardly hold our attention, except the merciless way in which Findley describes His Majesty's neurosis. The metafictional method, more evident than in The Wars, is, however, less effective in winning the reader's interest. Referring to Findley's book and to Chriss Scott's Antichton, Linda Hutcheon has this to say:

These works are not historical novels in the traditional sense, for they are also very metafictional in their attention to the processes of writing, reading, and interpreting. They are both self-consciously fictional but also overtly concerned with the acts (and consequences) of the reading and writing of history as well as fiction. In other words, the aesthetic and the social, the present and the past, are not separable discourses in these 
novels. They represent a postmodern self-reflexivity that moves outward to the world beyond their borders-to history, biography, philosophy, religion, politics. (134)

Therefore, Famous Last Words stands out as a more ambitious novel than The Wars, but, unfortunately, less successful from the reader's point of view, though not completely manqué. John Moss, who had been exceptionally hard in his criticism of The Wars, has at least more than one good word to say in favor of its sequel:

With great finesse, Findley violates the rules of verisimilitude. Mauberley tells the story yet tells of situations he could not possibly have witnessed. Findley tells of Mauberley, his last days and death, in a narrative that contains Mauberley's, and contains Quinn's as well. Findley creates fiction; within the fiction. Mauberley insists that what he says is true; within his truth, he describes what he could not possibly know, except through fiction-that is, by invention. Findley's violations are clearly an intentional affront to the principles of realism, which insist that fiction and factuality are mutually exclusive, and external reality is irrelevant.

Famous Last Words is an ambitious and curiously unsatisfying novel. It is important within the canon of Findley's work, following the strident power of The Wars, anticipating the exhilirating extravagance of Not Wanted on the Voyage. It poses great questions-somewhat awkwardly. And mercifully, it does not condescend to give the answers (113).

\section{Works Cited}

Cameron, Donald. Conversations with Contemporary Novelists. Toronto: Macmillan, 1973.

Findley, Timothy. Famous Last Words. Hardmondsworth: Penguin, 1989. . The Wars. Hardmondsworth: Penguin, 1986.

Hutcheon, Linda. The Canadian Postmodern: A Study of Contemporary English Canadian Fiction. Toronto: Oxford UP, 1988.

Lodge, David. The Modes of Modern Writing. London: Arnold, 1977.

Meywr, B., and O'Riordan, B. In Their Words. Toronto: Anansi, 1984.

Moss, John. The Reader's Guide to the Canadian Novel. 2nd. ed. Toronto: McClelland, 1987.

Timanov, Vladimir. "De-Automatization in Timothy Findley's The Wars." Canadian Literature, Autumn, 1991. 